\title{
Progress in Clinical Neurosciences: Parkinson's Disease with Dementia and Dementia with Lewy Bodies
}

\author{
Richard Camicioli and Nancy Fisher
}

\begin{abstract}
Dementia occurs in up to $30 \%$ of people with Parkinson's disease and is a major cause of disability. Pathologically, Parkinson's dementia, where dementia follows the onset of parkinsonism by at least one year, overlaps with dementia with Lewy bodies. We review the functional impact, definitions, neuropsychology, epidemiology and pathophysiology of Parkinson's dementia, dementia with Lewy bodies and their overlap. Associated psychiatric and imaging findings are also considered. Lastly, current and emerging approaches to assessment and treatment in patients with these Lewy body associated dementias are presented.
\end{abstract}

RÉSUMÉ: Maladie de Parkinson avec démence et démence à corps de Lewy. La démence est présente chez plus de 30\% des patients atteints de la maladie de Parkinson et constitue une cause importante d'invalidité. Au point de vue anatomopathologique, la démence de la maladie de Parkinson (DMP) apparaissant au moins un an après le début de la maladie chevauche la démence à corps de Lewy (DCL). Nous révisons l'impact fonctionnel, les définitions, la neuropsychologie, l'épidémiologie et la physiopathologie de la DMP et de la DCL et leur chevauchement. Les manifestations psychiatriques et l'imagerie sont également discutées. Finalement, les approches actuelles et émergentes d'évaluation et de traitement chez les patients porteurs de ces démences à corps de Lewy sont présentées.

Can. J. Neurol. Sci. 2004; 31: 7-21

Parkinson's disease (PD) is the most common neurodegenerative movement disorder, affecting about $0.5-5 \%$ of the population older than age 65 , both in European and nonEuropean populations. ${ }^{1,2}$ The prevalence of PD increases with age in most studies from less than $1 \%$ in people aged 65-69 years to $2-3 \%$ or more in people older than age 90 . The prevalence might decrease in the very elderly, possibly reflecting diagnostic uncertainty, overlap with other diseases, a disproportionate effect on survival in the oldest old with PD or inadequate sample sizes in studies of the oldest old (greater than age 85 years). ${ }^{3,4}$ At a societal level, PD increases health care utilization and costs. ${ }^{5,6}$

Parkinson's disease is a progressive disorder associated with acquired parkinsonism and the loss of substantia nigra neurons in the presence of Lewy bodies (http://www.ICDNS.org). Parkinsonism is defined by the presence of two cardinal signs among resting tremor, rigidity, bradykinesia and postural or gait impairment, and can be caused by disorders other than idiopathic PD. Lewy bodies are eosinophilic inclusions that stain with antibodies directed against alpha-synuclein, a ubiquitous synaptic protein evident in a number of neurodegenerative disorders. ${ }^{7}$ Clinical features that make a diagnosis of idiopathic PD more likely include asymmetrical onset, resting tremor, and a favorable response to levodopa. ${ }^{8}$ Good accuracy (approximately $90 \%$ positive predictive value) and sensitivity (90\%) can now be achieved. ${ }^{9,10}$ Nevertheless in the general medical setting parkinsonism is often not diagnosed and specific diagnoses may be inaccurate. ${ }^{11}$

\section{Parkinsonism and Dementia}

Both PD and other disorders causing parkinsonism can be associated with dementia and cognitive impairment (Table 1). Dementia can be defined by the presence of an acquired cognitive disorder, affecting two cognitive domains (i.e., among memory, language, praxis, visuospatial function and executive function), leading to a decline in activities of daily living. ${ }^{12,13}$ Nevertheless, definitions differ between studies (see Definition of Dementia, below). The population prevalence of PD, parkinsonism and the degree of accompanying cognitive impairment vary depending on study methods (methods for caseascertainment and diagnostic definitions) and the age of the

From the Department of Medicine, Division of Neurology, University of Alberta (RC); and Neuropsychology Program, Department of Neurosciences, University of Alberta Hospital, Neuromodulation Program, Capital Health Authority (NF), Edmonton, Alberta, Canada.

ReCEived March 5, 2003. AcCePted infinalform June 25, 2003. Reprint requests to: Richard Camicioli, Department of Medicine (Neurology), University of Alberta, Glenrose Rehabilitation Hospital, E223, 10230-1 11th Avenue, Edmonton, Alberta, Canada T5G 0B7 
Table 1: Causes of parkinsonism associated with dementia in older adults.

\section{Lewy Bodies Disorders \\ Parkinson's disease \\ Dementia with Lewy bodies}

\section{Other Movement Disorders \\ Progressive supranuclear palsy \\ Corticobasal degeneration \\ Multiple system atrophy \\ Huntington disease}

\section{Primary Dementias}

Frontotemporal dementia

Alzheimer's disease

\section{Other Disorders}

Cerebrovascular disease

Normal pressure hydrocephalus

ALS-PD-Dementia Complex of Guam

HIV Dementia

Creutzfeld-Jakob Disease population under study. In most studies the prevalence of dementia associated with PD is $20-40 \%$ with an incidence of 2.69.5 cases per 100 patient-years of observation. ${ }^{4,11,14-27}$ The recent recognition of Dementia with Lewy bodies (DLB), wherein dementia and parkinsonism may occur within one year of each other and are accompanied by cognitive fluctuations and hallucinations, has both complicated and illuminated our understanding of the role of Lewy body pathology in causing dementia with parkinsonism. Although a number of studies have addressed the epidemiology of Parkinson's dementia (PDD), the epidemiology of DLB is not as clear. ${ }^{28,29}$

\section{ImPact on Quality of Life, Autonomy and Mortality}

The effect of PD on quality of life correlates with progression of symptoms and is most closely related to depression, disability, postural impairment and cognitive impairment. ${ }^{30,31}$ The degree of cognitive impairment affecting executive function in patients with PD is associated with impaired decision making capacity. ${ }^{32}$ Moreover, PD is associated with long term care placement in Canada. ${ }^{33}$ Independent risk factors for nursing home placement among patients with PD include older age, functional impairment, cognitive impairment and hallucinations. ${ }^{34,35}$

In addition to affecting independence, and despite the availability of effective treatments for PD, PD and parkinsonism are associated with increased mortality. ${ }^{36-39}$ Parkinson's dementia confers an increased risk of mortality regardless of whether the patient is living in the community ${ }^{40}$ or in a nursing home. ${ }^{41}$ Given the potential impact of cognitive deficits on meaningful clinical outcomes, its early identification in PD and of PDD and related conditions is important for future planning.

\section{Definitions of Dementia (Table 2)}

Several different classification systems are used to diagnose dementia in PD (see Table 2). Among these are the criteria of Cummings and Benson, ${ }^{42}$ International Classification for Disease (ICD)- $9,{ }^{43}$ ICD-10, ${ }^{44}$ the Diagnostic and Statistical Manual (DSM)-III, ${ }^{45}$ DSM-III-R, ${ }^{46}$ and the DSM-IV. ${ }^{47}$ It is clear from examination of Table 2 that a patient could fulfill the criteria for one diagnostic system yet not another. For example, many patients without functional decline and/or memory impairment might meet Cummings and Benson criteria, but would not meet the DSM criteria. The ICD-9 criteria imply that executive dysfunction and memory impairment are both mandatory for the diagnosis. The ICD-10 criteria are vague with respect to whether memory impairment and functional decline are required. Psychiatric etiologies of cognitive disturbance are not specifically excluded in the Cummings and Benson criteria, but are exclusionary in the DSM systems. The variability in definitions used in research contributes to the wide range of PDD prevalence rates, and the inconsistencies reported between studies examining cognition in PD versus PDD.

It could be argued that none of the above diagnostic systems is adequate with respect to PDD. Functional decline related to cognitive decline, as required by the DSM criteria, is often difficult to discern in the PD population due to motor difficulties. None of the above systems classify subtypes of the disorder. Furthermore, no operational criteria specific to PDD are available. A consensus conference should be held to produce operational guidelines outlining specific systematic research criteria for diagnosing dementia in PD (i.e., akin to the NINCDSADRDA Work Group for Alzheimer's disease (AD), ${ }^{48}$ and the Consensus guidelines for diagnosis of $\mathrm{DLB}^{49}$ ).

\section{Neuropsychological Distinction of Cortical Versus SubCORTICAL DEMENTIA}

Dementia in PD is commonly labeled "subcortical", entailing slowing of cognitive and motor skills, poor free recall of information in the context of relatively preserved recognition memory (i.e., suggesting a memory retrieval deficit), executive dysfunction (e.g., loss of cognitive flexibility) and mood disturbance (e.g., depression). ${ }^{50,51}$ Aphasia, apraxia, agnosia and severe amnesia are uncommon. ${ }^{42}$ This is in contrast to a "cortical" dementia picture (e.g., AD) which involves deficits in language and visuospatial functioning and a memory pattern categorized by impaired learning, and rapid forgetting (i.e., no benefit from recognition trials).

Many neuropsychological studies support this distinction. ${ }^{52,53}$ For example, although both AD and PD patients have impaired learning and recall, PD patients show evidence of a primacy effect with relative sparing of recognition memory on word list tasks, compared to AD patients who show a reduced primacy effect and poor recognition memory. ${ }^{54}$ This suggests a retrieval deficit in PD as opposed to a storage deficit in AD, and corresponds to a subcortical (i.e., frontal-subcortical) pattern of memory disruption in PD as opposed to a cortical deficit in AD (i.e., temporal-hippocampal).

The utility of the cortical-subcortical dementia distinction has been questioned as simplistic and inaccurate. In PD, frontalsubcortical circuitry is affected, implicating disruption of both 
Table 2: Definitions of Dementia

\begin{tabular}{|c|c|c|c|c|}
\hline Diagnostic System & MI Required & $\begin{array}{l}\text { Other Cognitive Impairment } \\
\text { Required }\end{array}$ & Functional Decline (ADL/IADL) & Other \\
\hline DSM-III & $\mathrm{Y}$ & $\begin{array}{l}\text { at least one of: impaired abstract } \\
\text { thinking; impaired judgment; } \\
\text { aphasia, apraxia, or agnosia; } \\
\text { constructional difficulty; } \\
\text { personality change }\end{array}$ & $\begin{array}{l}\text { interferes with social or } \\
\text { occupational functioning }\end{array}$ & $\begin{array}{l}\text { Evidence of organic factor judged } \\
\text { to be etiologically related or an } \\
\text { organic etiologic factor can be } \\
\text { presumed if conditions other than } \\
\text { organic mental disorders have been } \\
\text { ruled out and if behavioural change } \\
\text { represents cognitive impairment in } \\
\text { a variety of areas }\end{array}$ \\
\hline$\overline{\text { DSM-III-R }}$ & $\begin{array}{l}\text { Y (STM and } \\
\text { LTM) }\end{array}$ & $\begin{array}{l}\text { at least one of: impaired abstract } \\
\text { thinking; impaired judgment; } \\
\text { aphasia, apraxia, or agnosia; } \\
\text { constructional difficulty; } \\
\text { personality change }\end{array}$ & $\begin{array}{l}\text { interferes with work or usual } \\
\text { social activities or relationships } \\
\text { with others }\end{array}$ & $\begin{array}{l}\text { Evidence of organic factor judged } \\
\text { to be etiologically related or an } \\
\text { organic etiologic factor can be } \\
\text { presumed if there is no psychiatric } \\
\text { disorder that could account for the } \\
\text { cognitive impairment }\end{array}$ \\
\hline DSM-IV & $\begin{array}{l}\text { Y (impaired } \\
\text { ability to learn } \\
\text { new info. or to } \\
\text { recall } \\
\text { previously } \\
\text { learned info.) }\end{array}$ & $\begin{array}{l}\text { at least one of: aphasia; agnosia; } \\
\text { apraxia; disturbance of executive } \\
\text { functioning }\end{array}$ & $\begin{array}{l}\text { cognitive deficits cause significant } \\
\text { impairment in social or } \\
\text { occupational functioning and } \\
\text { represent a decline from previous } \\
\text { level of functioning }\end{array}$ & $\begin{array}{l}\text { PD dementia characterized by } \\
\text { cognitive and motor slowing, } \\
\text { executive dysfunction and memory } \\
\text { retrieval problems; not better } \\
\text { accounted for by psychiatric } \\
\text { disorder }\end{array}$ \\
\hline ICD-9 & $\mathrm{Y}$ & $\begin{array}{l}\text { impairment of memory and } \\
\text { abstract thinking, the ability to } \\
\text { learn new skills, problem- } \\
\text { solving, and judgment }\end{array}$ & $\begin{array}{l}\text { interferes with occupational } \\
\text { and/or social performance }\end{array}$ & $\begin{array}{l}\text { Cognitive impairment often } \\
\text { accompanied by personality change } \\
\text { or impaired impulse control }\end{array}$ \\
\hline $\begin{array}{l}\text { Cummings and } \\
\text { Benson (1992) }\end{array}$ & $\mathrm{N}$ & $\begin{array}{l}\text { acquired deficits in at least } 3 \text { of } \\
\text { the following: language; memory; } \\
\text { visuospatial skills; emotional; } \\
\text { personality; calculation; } \\
\text { abstraction; judgment; executive } \\
\text { function }\end{array}$ & $\mathrm{N}$ & $\begin{array}{l}\text { Includes psychiatric, structural, } \\
\text { metabolic and toxic etiologies }\end{array}$ \\
\hline
\end{tabular}

$\mathrm{ADL}=$ Activities of Daily Living

IADL = Instrumental Activities of Daily Living

LTM = Long-term Memory

MI = Memory Impairment

STM = Short Term Memory

$\mathrm{Y}=\mathrm{Yes} ; \mathrm{N}=\mathrm{No}$ 
systems. ${ }^{55}$ Furthermore, cortical changes occur in $\mathrm{PD}^{56,57}$ and in $\mathrm{DLB}^{58}$ and there is evidence of subcortical in addition to cortical degeneration in AD. ${ }^{59,60}$ Moreover, damage to subcortical structures (e.g., thalamus and basal ganglia) can cause "cortical" symptoms such as aphasia, and visuospatial difficulties have been reported in subcortical dementias. ${ }^{55}$ If these limitations are recognized, as a general scheme for differentiating clinical cognitive deficit patterns or behavioral syndromes, the corticalsubcortical distinction can be helpful. ${ }^{50,61}$ The term "frontalsubcortical" has been used increasingly to describe PD and other "subcortical" dementias while the relative contributions of "cortical" and "subcortical" changes remain to be fully elucidated.

\section{Psychometric measures in PD, PDD AND DLB}

Some researchers classify patients as demented or nondemented on the basis of scores on psychometric rating scales or mental status examinations. Cut-off scores of less than 123 on the Mattis Dementia Rating Scale ${ }^{62}$ or less than 24 on the Mini Mental State Examination ${ }^{63}$ have been used in this manner, and represent performance two standard deviations below the normative mean. These measures do not account for age and education and have several psychometric weaknesses. ${ }^{64}$ They are more useful for staging progress/severity rather than for diagnostic classification.

Specific and unique cognitive patterns have been identified for PD, PDD, and DLB by investigators employing comprehensive standardized neuropsychological batteries. Identification of distinct cognitive profiles contrasting PD and PDD supports a subtype model rather than a simple progression model. ${ }^{65,66}$ There has also been a suggestion of distinct neuropsychological profiles based on etiology of PD (e.g., sporadic versus familial) ${ }^{67}$ In this small study, patients in both groups (who did not differ with regard to several indicators of disease severity) demonstrated impaired executive functioning, but only those with sporadic PD showed explicit memory recall impairment.

\section{Parkinson's Disease}

Parkinson's disease patients without dementia often have impairments on standardized cognitive tests. ${ }^{68}$ Many studies are limited by low statistical power, however, and this has led to inconsistencies in the literature. ${ }^{69}$ Other factors contributing to these inconsistencies include differing criteria for ruling out dementia, heterogeneous PD samples, variations in methodologies and measures utilized, differences in duration of illness, and varying degrees of control regarding medication regimens. Generalities from better designed studies are reviewed here.

In PD without dementia, simple verbal attentional skills (e.g., Digit Span) are typically preserved. ${ }^{70-75}$ Mild impairment on visual attention span tasks has been reported by some authors ${ }^{76}$ but not others. ${ }^{73}$ Working memory is reduced, notably on more complex measures with dual-task properties. ${ }^{71,75,77}$ Learning efficiency and free recall is generally mildly reduced compared to normal controls ${ }^{73,77-79}$ although a few studies do not report declines. ${ }^{80}$ Recognition memory is typically intact ${ }^{72,78-80}$ although this may be impaired in patients who are taking antiParkinsonian medication. ${ }^{69}$ Long-term (i.e., semantic) memory ${ }^{65}$ and remote memory ${ }^{72}$ are spared. Psychomotor slowing and increased response latencies are commonly observed ${ }^{76,78,81}$ and may account for deficits observed on tasks of higher order cognitive processing, which require a certain minimal speed of processing. ${ }^{82}$ Some investigators have reported impairments on language measures while others have not. ${ }^{70,83,84} \mathrm{~A}$ meta-analysis suggested relative sparing of verbal skills. ${ }^{72}$ Some investigators report specific visuospatial declines among PD patients without dementia, ${ }^{70,73,85}$ but others do not. ${ }^{78,85}$ These differences may, in part, relate to primary decreases in psychomotor speed or motor control, abilities often required on visual (e.g., timed) tasks. Zakzanis and Freedman ${ }^{72}$ in their meta-analysis, found visuospatial tasks to be minimally affected. Impairment of executive function is most consistently reported in the literature and is often the earliest detectable area of cognitive decline. This includes performance on problem-solving tasks, such as the Wisconsin Card Sorting Test and the Odd-Man-Out task, that require concept formation, spontaneous generation of efficient strategies, set-shifting and the use of feedback to modify response patterns. ${ }^{73,77,78,86}$

\section{Parkinson's Disease with Dementia}

The dementia of PD may exhibit a "frontal-subcortical" pattern with deficits in problem-solving, speed of processing, learning efficiency, and recall (with relative sparing of recognition memory). ${ }^{51}$ Compared to nondemented PD patients, some studies report that PDD patients perform worse on measures of learning efficiency and long delay free word-list recall but not on recognition trials. ${ }^{83}$ Others report that PDD patients perform worse on recognition trials compared to both PD patients and normals. ${ }^{87}$ A recent meta-analysis suggested that PDD patients exhibit impairment on recognition measures relative to controls, and that they perform worse than nondemented PD patients. ${ }^{6}$ Many studies of PDD patients report relative sparing of recognition memory compared to other types of demented patients (e.g., Alzheimer's patients), yet significantly lower performances compared to normals. ${ }^{54}$

Long-term semantic recall is typically spared in $\mathrm{PDD}^{65,88,89}$ as is simple attention span. ${ }^{90}$ Parkinson's dementia patients show mild deficits on verbal measures. ${ }^{72}$ For example, PDD patients are impaired compared to normals and PD patients on letter, category and verb production (i.e., action word fluency) tasks. $^{83,87}$ In one study, PDD patients performed significantly worse than PD patients on the Boston Naming Test. ${ }^{83}$ Zakzanis and Freedman ${ }^{72}$ reported that category (i.e., semantic) fluency, WAIS-R Performance IQ, and Purdue Pegboard scores were capable of discriminating PDD patients from normal controls (i.e., less than $5 \%$ overlap in test score distributions). Patients with PDD are impaired on problem-solving tasks involving concept formation, hypothesis testing and set-shifting. ${ }^{89}$ Psychomotor slowing is also evident in PDD and decisionmaking time on choice reaction time tasks is substantially worse compared to nondemented PD patients. ${ }^{81}$

\section{DEMENTIA WITH LEWY BODIES}

Lewy body disease may present as a combined corticalsubcortical picture ${ }^{61,91}$ that includes deficits in memory, visuospatial function, language, executive function, attention and psychomotor speed. The neuropsychological DLB literature 
is marked by small sample sizes and variability in terms of how DLB is defined (e.g., neuropathological evidence of DLB+AD (i.e., Lewy body variant of AD), neuropathologically pure DLB (i.e., without AD), use of DLB clinical criteria only). Visuospatial/visuoconstructional performance (e.g., Block Design, copy tasks, shape detection, fragmented letter tasks, etc.) is disproportionally and more severely impaired than typically observed among AD patients. ${ }^{91-100}$ On the clock drawing/ copying task, patients with DLB do not improve on the copy portion of the task, as do patients with PD and AD. ${ }^{94,101}$ Psychomotor speed is reduced compared with AD patients.94,95,98

Impairment on verbal fluency (FAS, Category) tasks has also been consistently reported..$^{91-94,101}$ As well, there is consistent evidence of equivalently impaired semantic memory/knowledge accessibility in AD and LBD. ${ }^{91,92,95}$ Hansen et al ${ }^{91}$ and Galasko et $\mathrm{al}^{95}$ reported equivalent impairment of $\mathrm{AD}$ and DLB patients on the Boston Naming Test and Category fluency tasks, yet disproportionate impairment by the DLB group on letter fluency. This is in contrast to the commonly observed AD verbal fluency pattern of letter fluency > category fluency. ${ }^{102}$ Lambon et $\mathrm{al}^{93}$ report similar findings, noting naming and verbal fluency impairments in DLB. Also, whereas the DLB group was equally impaired on the two tasks, this group's letter fluency was significantly inferior to that of the $\mathrm{AD}$ group. Calderon et $\mathrm{al}^{92}$ reported equally impaired naming, category fluency and letter fluency between groups of DLB and AD patients, and a trend toward inferior performance on letter fluency by DLB patients.

Patients with DLB are significantly impaired on attentional tasks including Digit Span, vigilance, sustained attention, divided attention, selective attention, and reaction time tasks. ${ }^{91,92,103,104}$ There is a suggestion that attentional deficits are more widespread and severe than seen in AD (e.g., see Calderon et $\mathrm{al}^{92}$ ). Comparison with AD samples with regard to Digit Span has produced inconsistent reports (see Lambon et $\mathrm{al}^{93}$ for review). Fluctuating attention/cognition is characteristic of the LBD syndrome. ${ }^{103,105,106}$ This can be assessed using observational methods amenable to clinical practice. ${ }^{107,108}$ Recent data suggest that cognitive fluctuation may also occur in PDD, blurring the distinction from DLB. ${ }^{109}$

Patients with DLB may be better oriented than AD patients. ${ }^{98,110}$ More severe memory loss than normally seen in PD is common, including impairments on recognition memory tasks. ${ }^{92,93,98}$ Episodic memory impairment is generally less severe than in $\mathrm{AD}^{92,94,98,100,110}$ although a few authors report memory impairment equal to that seen in AD. ${ }^{91,95}$ The finding of equally severe memory impairment in LBD and AD groups by Hansen et $\mathrm{al}^{91}$ and Galasko et $\mathrm{al}^{95}$ may be related to the fact that their Lewy body groups showed mixed neuropathology (AD+LBD). In neuropathologically pure DLB patients, Salmon et $\mathrm{al}^{94}$ found significant impairments on all aspects of a verbal learning and recall task (i.e., California Verbal Learning Test), without the typical pattern or severity of losses observed in AD. For example, recognition memory was not exceptionally impaired, and their group did not show an increased propensity for intrusion errors when cued.

Dementia with Lewy bodies patients generally have difficulty in executive function compared to matched controls (e.g., Trails B, Similarities, card sorting tests). ${ }^{91,94,99,101}$ Because the initial clinical presentation of DLB can be very similar to AD (with memory complaints and only minimal extrapyramidal signs), referral to a neuropsychologist for detailed assessment may be useful diagnostically.

\section{INCIDENCE STUDIES OF PDD}

Incidence studies offer many advantages over cross-sectional prevalence studies including the prospective identification of risk factors for disease and outcomes such as mortality (Table 3). Because of differential mortality, ${ }^{39,40}$ prevalence studies do not reflect the true impact of dementia in PD. ${ }^{111}$ Incidence rates in recent studies range from as low as approximately 2.1 per 100 patient years of observation in an earlier clinic based sample ${ }^{21}$ with a mean age of 56 years to as high as 9.5 per 100 patient years in a recent population-based study that had a mean age of 70 years. $^{26}$ In general, participants who are older and more cognitively impaired are less likely to participate and more likely to withdraw from studies. ${ }^{112}$ Patients referred to clinics may differ from those in population-based studies. For example, movement disorder clinics might be referred younger or more complicated patients. In contrast to PDD there are no current incidence studies of DLB, reflecting the difficulty in separating the onsets of cognitive and motor impairment, and its more recent definition.

\section{RISK FACTORS FOR PDD (Table 3)}

A case control study of risk factors for PDD identified education (less than high school), motor severity and an older age of onset as predictors. ${ }^{113}$ Incidence studies have identified similar factors. Older age, worse motor function, and axial motor impairment are associated with dementia. ${ }^{24-26}$ While global cognitive impairment is associated with dementia risk, specific

\section{Table 3: Risk factors for dementia in Parkinson's disease}

Demographic

Older age 21,24-26 $^{2}$

Older age at onset ${ }^{22,23,113}$

Longer disease duration ${ }^{26}$

Male gender ${ }^{25}$

Education $^{25,113}$

Motor impairment

Worse motor impairment ${ }^{21,22,24,26}$

Axial motor impairment and bradykinesia ${ }^{25}$

Cognitive

Worse global cognitive function ${ }^{21,26}$

Auditory verbal learning and nonverbal reasoning 22

Picture completion, Stroop interference, verbal fluency ${ }^{23}$

Verbal fluency ${ }^{114}$

Executive function and verbal learning ${ }^{115}$

Psychiatric

Psychosis ${ }^{26}$

Environmental

Smoking ${ }^{16,116}$

Estrogen use as protective ${ }^{117}$ 
aspects of cognitive function that have been identified include measures of verbal fluency, ${ }^{114}$ verbal memory and executive function. ${ }^{115}$ One study showed impairment on the Picture Completion subtest of the WAIS-R, raising the possibility that aspects of visuospatial function may be predictive. ${ }^{23}$ A study that examined shared risk factors between AD and PDD found that smoking history predicted dementia in PD while head injury, hypertension and diabetes were not associated with PDD. ${ }^{116}$ Estrogen use was a protective factor in some studies. ${ }^{117,118}$

\section{GeNeTIC Risks AND PDD}

The role of genetic factors in PDD is supported by the increased risk of dementia (including AD) in family members of patients with PDD. ${ }^{119,120}$ The effect of polymorphisms associated with an increased risk of AD on the risk of dementia in PD is not clear. One recent study, ${ }^{121}$ but not the majority, ${ }^{122,123}$ showed an association between the Apolipoprotein E epsilon 4 (Apo E ع4) allele and increased dementia risk in PD. In another, the Apo E e2 allele increased the risk of PDD. ${ }^{124}$ Differences between studies might reflect pathological heterogeneity in PDD; for example, PD patients with coexistent AD pathology might have an overrepresentation of the Apo E $\varepsilon 4$ allele, ${ }^{125,126}$ but this has not been confirmed. ${ }^{127}$ The Apo E $\varepsilon 4$ may be a shared risk factor for these disorders. ${ }^{128,129}$ Dipeptidyl-carboxypeptidase 1 was found to be associated with PD with coexistent AD pathology while butyrylcholinesterase and estrogen receptor polymorphisms were not. ${ }^{130,131}$ One study found an association with PDD and estrogen receptor gene polymorphisms in a Japanese population. ${ }^{132}$ Mitochondrial genes have been implicated in both AD and PD. ${ }^{133}$

Cases of familial DLB have been described. ${ }^{134-136}$ Studies of DLB generally show an association with Apo E ع4. ${ }^{137-139}$ Other genes associated with $\mathrm{AD}$ that have been examined in relation to DLB include polymorphisms in the amyloid precursor protein, ${ }^{140}$ alpha2-macroglobulin, ${ }^{141}$ presenilin $1,{ }^{142}$ and alpha-1 antichymotrypsin $^{143}$ with no clear association. A gene associated with peripheral dopamine metabolism, CYP2D6, has been associated with DLB in some ${ }^{144}$ but not all studies. ${ }^{145}$ Agedependent changes in prevalence of alleles, as exemplified by the CYP2D6 allele, might affect results. ${ }^{146}$ Mitochondrial genes, ${ }^{147}$ and monoamine oxidase polymorphisms, ${ }^{148}$ have been examined with conflicting results.

An association between PD and the tau gene, including polymorphisms associated with progressive supranuclear palsy and corticobasal degeneration, has been described in some studies ${ }^{149,150}$ but was not confirmed in a pathologically proven sample ${ }^{151}$ and the relationship between tau polymorphism and dementia risk has not been examined. ${ }^{152}$ Other loci may be involved in PD. ${ }^{153}$ The association between tau mutations and frontotemporal dementia, often with parkinsonism (but without Lewy bodies) makes this an important candidate gene for PDD.

Dementia has been observed in autosomal dominant familial PD. ${ }^{154,155}$ In a study that examined cognitive function in patients with familial PD, deficits were observed among family members, ${ }^{156}$ consistent with a study where family members of PD patients showed motor deficits. ${ }^{157}$
Psychosis and Parkinsonism: PD, PDD, DLB ANd their OVERLAP

Hallucinations are common in PD and are included in the core criteria for DLB. There is debate as to whether or not these constitute two separable disorders. ${ }^{158}$ Dementia with Lewy bodies is defined as a dementia occurring in association with two signs or symptoms among parkinsonism, visual hallucinations and cognitive fluctuations ${ }^{29}$ (see Table 4 contrasting PDD and DLB). Patients may have additional manifestations including frequent falls, syncope and additional psychiatric symptoms. ${ }^{29,159-161}$ Hallucinations and delusions occur in PD, PDD and DLB with increasing frequency, while depression may be equally frequent in each of these disorders. ${ }^{162,163}$ By the original convention, dementia and parkinsonism occur within one year of each other in DLB; however, DLB overlaps pathologically with PD. Recent studies have specified that clinical parkinsonism should have been present for at least two years to assure that PD patients have clear onset of motor signs prior to dementia. ${ }^{164}$ Cognitive fluctuations, thought to be suggestive of DLB, also occur in PD. ${ }^{109}$ Pathologic changes of $\mathrm{AD}$, specifically amyloid plaques, may or may not coexist with Lewy bodies that are diffusely distributed throughout the neocortex. ${ }^{158,165}$ Patients with PD who develop early hallucinations (within one year of treatment) are likely to have a premorbid psychotic illness or DLB. ${ }^{166}$ One key clinical feature in DLB is the presence of dramatic neuroleptic sensitivity to conventional and even some atypical neuroleptics in many patients. ${ }^{167}$ The recognition of DLB has allowed more prudent treatment of these patients with specific atypical neuroleptics such as clozapine or quetiapine, agents that are also effective for psychosis in PD. The basis of hallucinations in DLB and PD is not known, but neurochemical heterogeneity ${ }^{168}$ or specific pathological involvement; for example, involvement of the temporal lobe, may be implicated. ${ }^{169}$ It has been suggested that REM sleep behavior disorder may be characteristic of Lewy body disorders and other synucleinopathies ${ }^{170}$ and that such problems may contribute to hallucinations. ${ }^{171} \mathrm{~A}$ comparison of extrapyramidal signs in DLB and PD, revealed more severe action tremor, axial symptoms and rigidity in DLB. ${ }^{172}$

Table 4: Contrasting the classic features of Parkinson's disease with dementia (PDD) with Dementia with Lewy Bodies (DLB).

\begin{tabular}{lll}
\hline & PDD & DLB \\
Parkinsonism & More than 1 year & Less than 1 year \\
Motor Signs & Fluctuating & Milder \\
Cognition & Stable & Fluctuating \\
Hallucinations & Drug Related & Independent of drugs \\
LB Pathology & LB/DLB & DLB \\
AD Pathology & Yes & Yes \\
Apo E \&4 risk & ?Onset & Association \\
\hline
\end{tabular}


Pathophysiologic Relationship between PDD, DLB AND Alzheimer's DISEASE

\section{Pathology}

Although the pathologic basis for PDD remains to be fully delineated, increasing evidence supports the notion that it is heterogeneous and that there may be progressive cortical involvement. ${ }^{173}$ Coexistent cortical Alzheimer pathology may contribute to decline in PD. ${ }^{174}$ However, such changes are not present to a sufficient degree to warrant a diagnosis of coexistent AD in most cases. ${ }^{165}$ Cortical Lewy bodies have been better recognized since the introduction of ubiquitin and alphasynuclein staining. Lewy body densities are significantly associated with cognitive impairment, independent of Alzheimer-type pathology. ${ }^{175,176}$ On the other hand many patients with PD without dementia have diffuse Lewy bodies ${ }^{177}$ and the presence of cortical Lewy bodies does not distinguish between DLB and PDD. While parahippocampal Lewy bodies were readily identified in one study, regardless of the designation DLB or PDD, DLB patients had more coexistent plaque pathology. ${ }^{58}$ Others have found weak correlations between cortical Lewy bodies and dementia. ${ }^{178,179}$ In addition to Lewy bodies, Lewy neurites are associated with dementia in both DLB and PDD, but can be found in cases of PD without dementia. Moreover, it is evident that alpha-synuclein staining can also be observed in AD and multiple system atrophy. ${ }^{7,161}$ The relationship with AD may be related to interactions between amyloid and alpha-synuclein toxicity that have been observed in model studies. ${ }^{180}$

\section{Neurochemistry}

The dopaminergic deficit in PD has been known since the 1960s. ${ }^{181}$ However, additional changes have been noted in cholinergic, ${ }^{182}$ noradrenergic ${ }^{183}$ and serotonergic systems. ${ }^{184}$ Cholinergic deficits, reflected in decreased frontal choline-acetyl transferase (ChAT) have been associated with cognitive impairment and dementia in PD. ${ }^{185}$ Similar changes have been found in DLB patients who died with mild impairment. ${ }^{186}$ Nicotinic changes may occur in PDD and DLB. ${ }^{187}$ Measures of serotonin turnover (5-HIAA/5-HT) relative to cholinergic function (5-HIAA/ChAT) may be associated with hallucinations in DLB, in contrast to decreased serotonin turnover in PD. ${ }^{188}$

Cognitive dysfunction has been related to diminished dopamine D1 and D3 receptor binding in PD and PDD. ${ }^{185,189}$ An impaired ability to compensate for loss of dopaminergic transmission may be suggested in DLB. ${ }^{190}$ The loss of D3 binding, reflecting mesolimbic dopaminergic neurons, might be associated with dopamine non-responsive symptoms. ${ }^{191}$

\section{Neuroimaging}

Deficiencies in $\left[{ }^{18} \mathrm{~F}\right]$ fluoro-dihydroxyphenylalanine by positron emssion tomography have been noted in PDD patients in the caudate, ventral striatum and anterior cingulate. ${ }^{192}$ Dementia with Lewy bodies can be differentiated from AD and PD on the basis of decreased dopamine transporter binding using [ $\left.{ }^{123} \mathrm{I}\right]$-betacarbomethoxy-3-beta-(4-iodophenyl)-nortropane, a pre-synaptic dopamine transporter marker: both PD and DLB show decreased transporter binding, which may be more severe in DLB, in keeping with the autopsy-based neurochemical studies. ${ }^{193,194}$

Changes in blood flow may correlate with frontal and global cognitive dysfunction in PD patients. ${ }^{195-197}$ Others have not been able to distinguish PDD from AD using ${ }^{[18 \mathrm{~F}]}$ fluorodeoxyglucose positron emission tomography. ${ }^{198-203}$ Decreases in perfusion or glucose metabolism in PDD compared to PD have been shown. ${ }^{204,205}$ Compared with matched AD patients, PDD patients show a greater decrease in occipital glucose metabolism, with sparing of medial temporal metabolism, ${ }^{206}$ findings reminiscent of DLB ${ }^{207}$ Cholinergic binding is reduced in PDD as in AD. ${ }^{208}$ One study showed that DLB, PD and AD could be distinguished by the pattern blood flow measured by $99 \mathrm{mTc}$ hexamethylpropylenamineoxime SPECT: DLB showed greater hypoperfusion compared to $\mathrm{PD}$, except in the frontal and occipital regions, and frontal perfusion was lower in DLB compared to AD. ${ }^{209}$ In DLB more occipital hypoperfusion may be evident, ${ }^{210-212}$ and temporoparietal hypoperfusion may correlate with cognitive function. ${ }^{213}$ In another study, decreased blood flow using 99mTc hexamethylpropylenamineoxime SPECT in LBD did not correlate with cognitive function, but was similar to that seen in AD patients. ${ }^{214}$

Structural imaging (e.g., CT, MRI) has been applied to the evaluation of dementia in PD. Atrophy on MRI is associated with cognitive decline in PD. ${ }^{215,216}$ Hippocampal atrophy can be seen in PD with and without dementia, ${ }^{217}$ a finding that was not replicated in another study, ${ }^{218}$ but shown in a study of older PD patients. ${ }^{219}$ Patients with DLB similarly show medial temporal atrophy, ${ }^{220}$ but to a lesser degree than in AD. This pattern in DLB, with sparing of medial temporal structures compared to $\mathrm{AD}$, has been confirmed by other investigators. ${ }^{21-223}$ Atrophy in the substantia inominata has likewise been observed in AD and other dementias, including PDD. ${ }^{224}$ Patients with DLB have a rate of brain atrophy similar to that observed in AD. ${ }^{225}$ Volumetric change of the basal ganglia or occipital lobe has not been seen in DLB, but white matter changes may be observed. ${ }^{226-228}$

Changes on MR spectroscopy in cortical N-acetyl aspartate/creatine ${ }^{229}$ are correlated with cognitive change, and are associated with dementia in $\mathrm{PD}^{87}$ - findings that offer the potential of a widely available dynamic biomarker for dementia in parkinsonian syndromes. Similarly, MR spectroscopy findings have been reported in DLB. ${ }^{230}$ In the future, developments in imaging promise to further advance the development of MRI as a biomarker in neurodegenerative disease as well as a differential diagnostic tool. ${ }^{231}$

\section{IMPACT OF FUNCTIONAL NEUROSURGERY ON COGNITION}

Although a complete review of cognitive consequences of stereotactic surgery for movement disorders is beyond the scope of this article, neuropsychological evaluation is considered a standard part of the presurgical work-up. ${ }^{232}$ This process allows for determination of whether the candidate has dementia or cognitive impairment, which increases risk for postoperative cognitive decline. Specific aspects of cognition may be affected by surgery. ${ }^{233}$ It is important to establish the person's cognitive capability to understand the decision to have surgery including the risks involved, to provide informed consent and to assess their ability to remain cooperative and alert during the procedure. Evaluation of depression, anxiety and psychiatric disturbance that could interfere with surgery, or be exacerbated by the surgical process, is also important. 


\section{Evaluation And Treatment of PDD}

\section{Evaluation}

Guidelines for the evaluation of people with dementia in the general population have been published, however it is unclear if these apply to PD patients who develop dementia. ${ }^{13,234-236}$ Since dementia is part of the natural history of PD, one might argue that blood work and neuroimaging might not be routinely necessary. ${ }^{237}$ In the community, even though it is unusual to identify completely reversible causes of dementia, it is more common to identify factors that might contribute to cognitive impairment. ${ }^{238}$ The greatest benefit is expected when reversible factors are treated and when patients have mild cognitive impairment. It would, therefore, seem prudent to identify dementia and cognitive impairment as it appears in PD patients and to tailor investigations based on clinical assessment, but not to deny patients an evaluation that might reveal occult contributors to cognitive decline.

Assessment of dementia in the patient with parkinsonism includes a careful history (e.g., focusing on the nature of the deficit, onset i.e., gradual vs. sudden and course, etc.) and examination. A review of systems and medications is important. Mental status evaluation using standardized instruments such as the Mini-Mental State Examination may be helpful, especially if a clear decline is documented. ${ }^{239}$ On the other hand the MiniMental State Examination is not sensitive to deficits in executive dysfunction, common in PD. ${ }^{240}$ The development of brief instruments sensitive to frontal dysfunction, such as the Frontal Assessment Battery and other, related instruments ${ }^{241,242}$ may partially fill this void. Nevertheless, it remains important to assess various aspects of individual cognitive domains, including memory, visuospatial function, language and praxis in patients with movement disorders in whom cognitive impairment is of concern. Referral to a neuropsychologist may be helpful in patients in whom cognitive dysfunction is of concern.

A psychiatric history addressing psychotic and depressive symptoms is important, given the prevalence of psychosis and depression in PD. ${ }^{243}$ Depression can be associated with impaired cognition. ${ }^{244}$ Assessment instruments that can be helpful for grading the degree of depressive symptoms are available. These include the Beck, ${ }^{245}$ Hamilton, ${ }^{246}$ Geriatric $^{247}$ and Cornell ${ }^{248}$ Depression Scales. The physical examination of patients with PDD should focus on the identification of potential medical conditions that might exacerbate cognitive dysfunction, including postural hypotension and illnesses unrelated to PD (e.g., pneumonia, congestive heart failure, malignancy, diabetes). New focal neurological signs may suggest cerebrovascular disease. One should also reevaluate the diagnosis, looking specifically for autonomic dysfunction, gaze abnormalities, dysmetria, pyramidal signs, neuropathy, and gait ataxia.

Laboratory testing for occult illness includes complete blood count, glucose, electrolytes, urea, creatinine, liver function tests, thyroid stimulating hormone, and a vitamin B12 level. If there is an acute change, suggesting a delirium, a work-up for infection should be included, along with metabolic studies and other assessments targeted by the history and physical examination. A rapid progression, focal signs, and prominent gait impairment raise the concern of additional intracranial pathology, motivating imaging.

\section{Treatment}

Reversible causes should be treated. In particular, medications that might be contributing to cognitive dysfunction should be discontinued. Anticholinergic medications are important to eliminate because they are associated with cognitive impairment. ${ }^{249-253}$ Psychosis can improve with reduction and elimination of some medications, particularly selegeline, amantadine and dopamine agonists. In some patients levodopa might have to be decreased. It is not as clear whether reducing antiparkinsonian medications improve cognition, but simplification of medication regimens is reasonable if cognitive impairment is identified. Changes in medication should be undertaken with caution due to the possibility of drug withdrawal delirium, as has been observed with amantadine $e^{254,255}$ and the risk of inducing neuroleptic malignant syndrome. ${ }^{256-259}$

Currently there are no approved cognition-enhancing drugs for patients with PD. Depression can be treated with counseling and medications. Psychosis that does not reverse with medication changes, or elimination of identifiable triggers can be treated with atypical antipsychotic medications. ${ }^{260}$ These include clozapine, quetiapine and olanzapine. Typical neuroleptics predictably worsen parkinsonism. ${ }^{261}$ Clozapine is the only agent that has been subject to a double blind placebo-controlled study for psychosis in PD, ${ }^{262}$ but must be monitored with weekly or two-weekly blood tests to monitor for agranulocytosis. A placebo-controlled trial that was designed to compare clozapine to olanzapine ${ }^{263}$ revealed worsened motor function with olanzapine. Another study found that olanzapine did not improve psychosis. ${ }^{264,265}$ Similar concerns apply in DLB. ${ }^{266}$ Quetiapine is an atypical antipsychotic that appears effective in open label experience, possibly with less (but not without) potential to exacerbate parkinsonism. ${ }^{267,268}$ The propensity for improving psychosis without extrapyramidal effects may relate to the kinetics of drug binding to D2 dopamine receptors, whose blockade leads to parkinsonism. ${ }^{269}$ Blockade of serotonergic recepters (5-HT2A) or subtypes of dopaminergic recepters may also be relevant.

Given the profound cholinergic deficits in PD and PDD, cholinergic enhancing medications are under evaluation in PDD. Nevertheless there remain concerns regarding the possibility of exacerbating motor symptoms. ${ }^{270,271}$ Aplacebo-controlled trial of rivastigmine, a cholinesterase inhibitor, has demonstrated cognitive and behavioral improvement in DLB. ${ }^{272}$ Open label experience with rivastigmine has been published for patients with PDD and has shown improvement of psychotic symptoms, sleep disturbance and caregiver distress. ${ }^{273,274}$ Improved psychosis has been similarly shown with donepezil. ${ }^{275,276}$ Recently, a placebocontrolled crossover study demonstrated significant improvement in PDD patients treated with donepezil. ${ }^{277}$ Open label benefits in cognitive function has also been reported for PDD with donepezil ${ }^{278}$ and tacrine. ${ }^{279}$ Medications that directly affect the nicotinergic system may have promise in PDD. ${ }^{280-282}$ Modulation of other neurotransmitter systems in treating cognitive decline has not been as extensively examined.

\section{Competency and advance directives}

Because of the cognitive declines often noted among PD patients, decision-making competence is sometimes called into question. For example, capacity to consent to medical treatment 
may be reduced by impaired executive function. Recent research on cognitively impaired PD patients reported impaired consent capacity under four different legal standards, particularly with regard to comprehension of treatment information (including risks and benefits) and the provision of rational/logical reasons for a treatment choice. ${ }^{32}$ Furthermore, performance on cognitive tests predicted performance on measures of three of the four legal competence standards. ${ }^{32}$ Neuropsychological assessment is often conducted to assist with competency assessment.

Even if the patient is cognitively competent, planning for the future is at issue in any progressive neurological condition. That is, it is important to plan for future health care and personal affairs. It is recommended that individuals prepare personal directive and enduring power of attorney documents at a time when they are cognitively competent, as a safeguard, in case cognitive difficulties progress. These documents vary in nature by jurisdiction. Typically, however, the personal/advanced directive allows for designation of an agent to make decisions on one's behalf should one become mentally/cognitively incompetent. Information covered includes not only the name of the individual to whom this decision-making power is designated, but also an outline of the individual's health care wishes. The Enduring Power of Attorney also names an agent, but this document is typically concerned only with management of the individual's financial affairs should they become cognitively incompetent. Declaration of incompetence by two health care professionals is typically required for activation of these documents. In most states/provinces, if an individual does not have a personal directive and Enduring Power of Attorney and has lost capacity, guardianship/trusteeship are sought (i.e., person is no longer capable of assigning an agent for a personal directive or power of attorney).

\section{SUMMARY}

Cognitive impairment is common in PD and is a major cause of disability. While clinical and psychological risk factors are continuing to be defined, it is likely that imaging and genetic predictors will soon be identified. This will provide insight into the pathophysiology of dementia in addition to predictive potential. Such studies will then need to be coupled with pathological investigations of well-defined, longitudinally assessed, cohorts of patients, as has been done in AD. This approach will allow the border-zone between Lewy body disorders and other age related disorders to be clarified. Clearly the future hope is to develop treatments that can accompany supportive management with the goal of preventing dementia.

\section{ACKNOWLEDGEMENTS}

We thank Sheri Foster for assistance with preparation of the manuscript and Dr. Wendy Johnston for helpful comments. We also thank the staff of the Glenrose Rehabilitation Hospital and Sandra Sebzda from the University of Alberta Hospital for assistance in retrieving references. Dr. Camicioli has received consulting fees or honoraria from Pfizer, Janssen Ortho, Glaxo-Smith-Kline and Novartis.

\section{REFERENCES}

1. Kis B, Schrag A, Ben-Shlomo Y, et al. Novel three-stage ascertainment method: prevalence of $\mathrm{PD}$ and parkinsonism in South Tyrol, Italy. Neurology 2002; 58:1820-1825.
2. Chen RC, Chang SF, Su CL, et al. Prevalence, incidence, and mortality of PD: a door-to-door survey in Ilan county, Taiwan. Neurology 2001; 57:1679-1686.

3. de Rijk MC, Launer LJ, Berger K, et al. Prevalence of Parkinson's disease in Europe: a collaborative study of population-based cohorts. Neurologic Diseases in the Elderly Research Group. Neurology 2000; 54:S21-S23.

4. Mayeux R, Denaro J, Hemenegildo N, et al. A population-based investigation of Parkinson's disease with and without dementia. Relationship to age and gender. Arch Neurol 1992; 49:492-497.

5. Murman DL, Chen Q, Colucci PM, et al. Comparison of healthcare utilization and direct costs in three degenerative dementias. Am J Geriatr Psychiatry 2002; 10:328-336.

6. Parashos SA, Maraganore DM, O’Brien PC, Rocca WA. Medical services utilization and prognosis in Parkinson disease: a population-based study. Mayo Clin Proc 2002; 77:918-925.

7. Goedert M. Parkinson's disease and other alpha-synucleinopathies. Clin Chem Lab Med 2001; 39:308-312.

8. Gelb DJ, Oliver E, Gilman S. Diagnostic criteria for Parkinson disease. Arch Neurol 1999; 56:33-39.

9. Hughes AJ, Daniel SE, Lees AJ. Improved accuracy of clinical diagnosis of Lewy body Parkinson's disease. Neurology 2001; 57:1497-1499.

10. Hughes AJ, Daniel SE, Ben-Shlomo Y, Lees AJ. The accuracy of diagnosis of parkinsonian syndromes in a specialist movement disorder service. Brain 2002; 125:861-870.

11. Meara J, Bhowmick BK, Hobson P. Accuracy of diagnosis in patients with presumed Parkinson's disease. Age Ageing 1999; 28:99-102.

12. American Psychiatric Association. Diagnostic criteria from DSMIV-TR. Washington, DC: American Psychiatric Association, 2000.

13. Knopman DS, DeKosky ST, Cummings JL, et al. Practice parameter: diagnosis of dementia (an evidence-based review). Report of the Quality Standards Subcommittee of the American Academy of Neurology. Neurology 2001; 56:1143-1153.

14. Snow B, Wiens M, Hertzman C, Calne D. A community survey of Parkinson's disease. CMAJ 1989; 141:418-422.

15. Ebmeier KP, Calder SA, Crawford JR, et al. Dementia in idiopathic Parkinson's disease: prevalence and relationship with symptoms and signs of parkinsonism. Psychol Med 1991; 21:69-76.

16. Ebmeier KP, Calder SA, Crawford JR, et al. Clinical features predicting dementia in idiopathic Parkinson's disease: a followup study. Neurology 1990; 40:1222-1224.

17. Tison F, Dartigues JF, Auriacombe S, et al. Dementia in Parkinson's disease: a population-based study in ambulatory and institutionalized individuals. Neurology 1995; 45:705-708.

18. Wang SJ, Fuh JL, Teng EL, et al. A door-to-door survey of Parkinson's disease in a Chinese population in Kinmen. Arch Neurol 1996; 53:66-71.

19. Aarsland D, Tandberg E, Larsen JP, Cummings JL. Frequency of dementia in Parkinson disease. Arch Neurol 1996; 53:538-542.

20. Bower JH, Maraganore DM, McDonnell SK, Rocca WA. Incidence and distribution of parkinsonism in Olmsted County, Minnesota, 1976-1990. Neurology 1999; 52:1214-1220.

21. Palazzini E, Soliveri P, Filippini G, et al. Progression of motor and cognitive impairment in Parkinson's disease. J Neurol 1995; 242:535-540.

22. Reid WGJ, Hely MA, Morris JGL, et al. A longitudinal study of Parkinson's disease: clinical and neuropsychological correlates of dementia. J Clin Neuroscience 1996; 3:327-333.

23. Mahieux F, Fenelon G, Flahault A, et al. Neuropsychological prediction of dementia in Parkinson's disease. J Neurol Neurosurg Psychiatry 1998; 64:178-183.

24. Hughes TA, Ross HF, Musa S, et al. A 10-year study of the incidence of and factors predicting dementia in Parkinson's disease. Neurology 2000; 54:1596-1602.

25. Levy G, Tang MX, Cote LJ, et al. Motor impairment in PD: relationship to incident dementia and age. Neurology 2000; 55:539-544.

26. Aarsland D, Andersen K, Larsen JP, et al. Risk of dementia in Parkinson's disease: a community-based, prospective study. Neurology 2001; 56:730-736. 
27. Rajput AH. Prevalence of dementia in Parkinson's disease. In: Huber SJ, Cummings JL, (Eds). Parkinson's Disease: Neurobehavioral Aspects. New York: Oxford University Press, 1992:119-131.

28. Stevens T, Livingston $\mathrm{G}$, Kitchen $\mathrm{G}$, et al. Islington study of dementia subtypes in the community. Br J Psychiatry 2002; 180:270-276.

29. McKeith IG, Ballard CG, Perry RH, et al. Prospective validation of consensus criteria for the diagnosis of dementia with Lewy bodies. Neurology 2000; 54:1050-1058.

30. Marinus J, Ramaker C, van Hilten JJ, Stiggelbout AM. Health related quality of life in Parkinson's disease: a systematic review of disease specific instruments. J Neurol Neurosurg Psychiatry 2002; 72:241-248.

31. Schrag A, Jahanshahi M, Quinn N. What contributes to quality of life in patients with Parkinson's disease? J Neurol Neurosurg Psychiatry 2000; 69:308-312.

32. Dymek MP, Atchison P, Harrell L, Marson DC. Competency to consent to medical treatment in cognitively impaired patients with Parkinson's disease. Neurology 2001; 56:17-24.

33. Rockwood K, Stolee P, McDowell I. Factors associated with institutionalization of older people in Canada: testing a multifactorial definition of frailty. J Am Geriatr Soc 1996; 44:578-582.

34. Aarsland D, Larsen JP, Tandberg E, Laake K. Predictors of nursing home placement in Parkinson's disease: a population-based, prospective study. J Am Geriatr Soc 2000; 48:938-942.

35. Goetz CG, Stebbins GT. Risk factors for nursing home placement in advanced Parkinson's disease. Neurology 1993; 43:2227-2229.

36. Morgante L, Salemi G, Meneghini F, et al. Parkinson disease survival: a population-based study. Arch Neurol 2000; 57:507-512.

37. Bennett DA, Beckett LA, Murray AM, et al. Prevalence of parkinsonian signs and associated mortality in a community population of older people. N Engl J Med 1996; 334:71-76.

38. Berger K, Breteler MM, Helmer C, et al. Prognosis with Parkinson's disease in Europe: a collaborative study of population-based cohorts. Neurologic Diseases in the Elderly Research Group. Neurology 2000; 54:S24-S27.

39. Mitchell SL, Rockwood K. The association between parkinsonism, Alzheimer's disease, and mortality: a comprehensive approach. J Am Geriatr Soc 2000; 48:422-425.

40. Louis ED, Marder K, Cote L, Tang M, Mayeux R. Mortality from Parkinson disease. Arch Neurol 1997; 54:260-264.

41. Fernandez HH, Lapane KL. Predictors of mortality among nursing home residents with a diagnosis of Parkinson's disease. Med Sci Monit 2002; 8:CR241-246.

42. Cummings JL, Benson DF. Dementia: A Clinical Approach. Boston: Butterworth-Heinemann, 1992.

43. U.S. Department of Health and Human Services. The international classification of diseases 9th Revision - Clinical Modification (ICD-9-CM). Vol. 1, 1980.

44. World Health Organization. The ICD-10 classification of mental and behavioural disorders: clinical descriptions and diagnostic guidelines. Geneva: World Health Organization, 1992.

45. American Psychiatric Association. Diagnostic and statistical manual of mental disorders: DSM-III. Washington, D.C.: American Psychiatric Association, 1982.

46. American Psychiatric Association. Diagnostic and statistical manual of mental disorders: DSM-III-R. Washington, DC: American Psychiatric Association, 1987.

47. American Psychiatric Association. Diagnostic and statistical manual of mental disorders: DSM-IV. Washington, DC: American Psychiatric Association, 1994.

48. McKhann G, Drachman D, Folstein M, et al. Clinical diagnosis of Alzheimer's disease: report of the NINCDS-ADRDA Work Group under the auspices of Department of Health and Human Services Task Force on Alzheimer's Disease. Neurology 1984; 34:939-944.

49. McKeith IG, Galasko D, Kosaka K, et al. Consensus guidelines for the clinical and pathologic diagnosis of dementia with Lewy bodies (DLB): report of the consortium on DLB international workshop. Neurology 1996; 47:1113-1124.
50. Cummings JL, Benson DF. Subcortical dementia. Review of an emerging concept. Arch Neurol 1984; 41:874-879.

51. Cummings JL. Introduction. In: Cummings JL, (Ed). Subcortical dementia. New York: Oxford, 1990:3-16.

52. La Rue A. Aging and neuropsychological assessment. Critical issues in neuropsychology. New York: Plenum Press, 1992.

53. Huber SJ, Shuttleworth EC, Paulson GW, Bellchambers MJ, Clapp LE. Cortical vs subcortical dementia. Neuropsychological differences. Arch Neurol 1986; 43:392-394.

54. Tierney MC, Nores A, Snow WG, et al. Use of the rey auditory verbal learning test in differentiating normal aging from Alzheimer's and Parkinson's Dementia. Psychol Assess 1994; 6:129-134.

55. Whitehouse PJ. The concept of subcortical and cortical dementia: another look. Ann Neurol 1986; 19:1-6.

56. Hakim AM, Mathieson G. Dementia in Parkinson disease: a neuropathologic study. Neurology 1979; 29:1209-1214.

57. Alvord EC. The pathology of Parkinsonism. In: Minckler J, (Ed). Pathology of the Nervous System. New York: McGraw-Hill, 1968:1152-1161.

58. Harding AJ, Halliday GM. Cortical Lewy body pathology in the diagnosis of dementia. Acta Neuropathol (Berl) 2001; 102:355363.

59. Mann DM, Esiri MM. The site of the earliest lesions of Alzheimer's disease. N Engl J Med 1988; 318:789-790.

60. Bondareff W, Mountjoy CQ, Roth M, et al. Age and histopathologic heterogeneity in Alzheimer's disease. Evidence for subtypes. Arch Gen Psychiatry 1987; 44:412-417.

61. Benke T. The neuropsychological assessment of dementia. CNS Spectrum 2002; 7:371-375

62. Mattis S. Dementia Rating Scale: Professional manual. Odessa, Florida: Psychological Assessment Resources, 1998.

63. Folstein MF, Folstein SE, McHugh PR. "Mini-mental state". A practical method for grading the cognitive state of patients for the clinician. J Psychiatr Res 1975; 12:189-198.

64. Spreen O, Strauss E. A Compendium of Neuropsychological Tests: Administration, Norms, and Commentary. New York: Oxford University Press, 1998.

65. McFadden L, Mohr E, Sampson M, Mendis T, Grimes JD. A profile analysis of demented and nondemented Parkinson's disease patients. Adv Neurol 1996; 69:339-341.

66. Graham JM, Sagar HJ. A data-driven approach to the study of heterogeneity in idiopathic Parkinson's disease: identification of three distinct subtypes. Mov Disord 1999; 14:10-20.

67. Dujardin K, Defebvre L, Grunberg C, Becquet E, Destee A. Memory and executive function in sporadic and familial Parkinson's disease. Brain 2001; 124:389-398.

68. Green J, McDonald WM, Vitek JL, et al. Cognitive impairments in advanced PD without dementia. Neurology 2002; 59:1320-1324.

69. Whittington CJ, Podd J, Kan MM. Recognition memory impairment in Parkinson's disease: power and meta-analyses. Neuropsychology 2000; 14:233-246.

70. Goldman WP, Baty JD, Buckles VD, Sahrmann S, Morris JC. Cognitive and motor functioning in Parkinson disease: subjects with and without questionable dementia. Arch Neurol 1998; 55:674-680.

71. Hoppe CD, Muller UD, Werheid KD, Thone AD, von Cramon YD. Digit Ordering Test: clinical, psychometric, and experimental evaluation of a verbal working memory test. Clin Neuropsychol 2000; $14: 38-55$.

72. Zakzanis KK, Freedman M. A neuropsychological comparison of demented and nondemented patients with Parkinson's disease. Appl Neuropsychol 1999; 6:129-146.

73. Levin BE, Llabre MM, Weiner WJ. Cognitive impairments associated with early Parkinson's disease. Neurology 1989; 39:557-561.

74. Huber SJ, Freidenberg DL, Shuttleworth EC, Paulson GW, Christy JA. Neuropsychological impairments associated with severity of Parkinson's disease. J Neuropsychiatry Clin Neurosci 1989; 1:154-158.

75. Bublak P, Muller U, Gron G, Reuter M, von Cramon DY. Manipulation of working memory information is impaired in 
Parkinson's disease and related to working memory capacity. Neuropsychology 2002; 16:577-590.

76. Peavy GM, Salmon D, Bear PI, et al. Detection of mild cognitive deficits in Parkinson's disease patients with the WAIS-R NI. J Int Neuropsychol Soc 2001; 7:535-543.

77. Cooper JA, Sagar HJ, Jordan N, Harvey NS, Sullivan EV. Cognitive impairment in early, untreated Parkinson's disease and its relationship to motor disability. Brain 1991; 114 (Pt 5):20952122.

78. Taylor AE, Saint-Cyr JA, Lang AE. Frontal lobe dysfunction in Parkinson's disease. The cortical focus of neostriatal outflow. Brain 1986; 109 (Pt 5):845-883.

79. Breen EK. Recall and recognition memory in Parkinson's disease. Cortex 1993; 29:91-102.

80. Ivory SJ, Knight RG, Longmore BE, Caradoc-Davies T. Verbal memory in nondemented patients with idiopathic Parkinson's disease. Neuropsychologia 1999; 37:817-828.

81. Pate DS, Margolin DI. Cognitive slowing in Parkinson's and Alzheimer's patients: distinguishing bradyphrenia from dementia. Neurology 1994; 44:669-674.

82. Grossman M, Zurif E, Lee C, et al. Information processing speed and sentence comprehension in Parkinson's disease. Neuropsychology 2002; 16:174-181.

83. Piatt AL, Fields JA, Paolo AM, Koller WC, Troster AI. Lexical, semantic, and action verbal fluency in Parkinson's disease with and without dementia. J Clin Exp Neuropsychol 1999; 21:435-443.

84. McPherson S, Cummings J. Neuropsychological aspects of Parkinson's disease and Parkinsonism. In: Grant I, Adams K, (Eds). Neuropsychological Assessment of Neuropsychiatric Disorders, 1996:288-311.

85. Katsarou Z, Bostantiopoulou S, Alevriadou A, et al. A longitudinal study of visuospatial discrimination in parkinsonian patients. Percept Mot Skills 1998; 86:171-180.

86. Richards M, Cote LJ, Stern Y. Executive function in Parkinson's disease: set-shifting or set-maintenance? J Clin Exp Neuropsychol 1993; 15:266-279.

87. Summerfield C, Gomez-Anson B, Tolosa E, et al. Dementia in Parkinson disease: a proton magnetic resonance spectroscopy study. Arch Neurol 2002; 59:1415-1420.

88. Mortimer JA, Pirozzolo FJ, Hansch EJ, Webster DD. Relationship of motor symptoms to intellectual deficits in Parkinson disease. Neurology 1982; 32:133-137.

89. Pillon B, Dubois B, Lhermitte F, Agid Y. Heterogeneity of cognitive impairment in progressive supranuclear palsy, Parkinson's disease, and Alzheimer's disease. Neurology 1986; 36:11791185.

90. Ross HF, Hughes TA, Boyd JL, et al. The evolution and profile of dementia in Parkinson's disease. Adv Neurol 1996; 69:343-347.

91. Hansen L, Salmon D, Galasko D, et al. The Lewy body variant of Alzheimer's disease: a clinical and pathologic entity. Neurology 1990; 40:1-8.

92. Calderon J, Perry RJ, Erzinclioglu SW, et al. Perception, attention, and working memory are disproportionately impaired in dementia with Lewy bodies compared with Alzheimer's disease. J Neurol Neurosurg Psychiatry 2001; 70:157-164.

93. Lambon RMA, Powell J, Howard D, et al. Semantic memory is impaired in both dementia with Lewy bodies and dementia of Alzheimer's type: a comparative neuropsychological study and literature review. J Neurol Neurosurg Psychiatry 2001; 70:149156.

94. Salmon DP, Galasko D, Hansen LA, et al. Neuropsychological deficits associated with diffuse Lewy body disease. Brain Cogn 1996; 31:148-165.

95. Galasko D, Katzman R, Salmon DP, Hansen L. Clinical and neuropathological findings in Lewy body dementias. Brain Cogn 1996; 31:166-175.

96. Mori E, Shimomura T, Fujimori M, et al. Visuoperceptual impairment in dementia with Lewy bodies. Arch Neurol 2000; 57:489-493.

97. Salmon D, Galasko D. Neuropsychological aspects of Lewy body dementia. In: Perry R, McKeith I, Perry E, (Eds). Dementia with Lewy Bodies. New York: Cambridge, 1996:99-114.
98. Shimomura T, Mori E, Yamashita $\mathrm{H}$, et al. Cognitive loss in dementia with Lewy bodies and Alzheimer disease. Arch Neurol 1998; 55:1547-1552.

99. Simard M, van Reekum R, Cohen T.A review of the cognitive and behavioral symptoms in dementia with Lewy bodies. J Neuropsychiatry Clin Neurosci 2000; 12:425-450.

100. Walker Z, Allan RL, Shergill S, Katona CL. Neuropsychological performance in Lewy body dementia and Alzheimer's disease. $\mathrm{Br}$ J Psychiatry 1997; 170:156-158.

101. Gnanalingham KK, Byrne EJ, Thornton A, Sambrook MA, Bannister P. Motor and cognitive function in Lewy body dementia: comparison with Alzheimer's and Parkinson's diseases. J Neurol Neurosurg Psychiatry 1997; 62:243-252.

102. Monsch AU, Bondi MW, Butters N, et al. A comparison of category and letter fluency in Alzheimer's disease and Huntington's disease. Neuropsychology 1994; 8:25-30.

103. Walker MP, Ayre GA, Cummings JL, et al. Quantifying fluctuation in dementia with Lewy bodies, Alzheimer's disease, and vascular dementia. Neurology 2000; 54:1616-1625.

104. Sahgal A, Galloway PH, McKeith IG. A comparative study of attentional deficits in senile dementias of Alzheimer and Lewy body types. Dementia 1992; 3:350-354.

105. Ballard C, O'Brien J, Gray A, et al. Attention and fluctuating attention in patients with dementia with Lewy bodies and Alzheimer disease. Arch Neurol 2001; 58:977-982.

106. McKeith IG. Dementia with Lewy bodies: clinical and pathological diagnosis. Alzheimer Reports 1998; 1:83-87.

107. Doubleday EK, Snowden JS, Varma AR, Neary D. Qualitative performance characteristics differentiate dementia with Lewy bodies and Alzheimer's disease. J Neurol Neurosurg Psychiatry 2002; 72:602-607.

108. Walker MP, Ayre GA, Cummings JL, et al. The Clinician Assessment of Fluctuation and the One Day Fluctuation Assessment Scale. Two methods to assess fluctuating confusion in dementia. Br J Psychiatry 2000; 177:252-256.

109. Ballard CG, Aarsland D, McKeith I, et al. Fluctuations in attention: PD dementia vs DLB with parkinsonism. Neurology 2002; 59:1714-1720.

110. Connor DJ, Salmon DP, Sandy TJ, et al. Cognitive profiles of autopsy-confirmed Lewy body variant vs pure Alzheimer disease. Arch Neurol 1998; 55:994-1000.

111. Marder K, Leung D, Tang M, et al. Are demented patients with Parkinson's disease accurately reflected in prevalence surveys? A survival analysis. Neurology 1991; 41:1240-1243.

112. Levin BE, Katzen HL, Klein B, Llabre ML. Cognitive decline affects subject attrition in longitudinal research. J Clin Exp Neuropsychol 2000; 22:580-586.

113. Glatt SL, Hubble JP, Lyons K, et al. Risk factors for dementia in Parkinson's disease: effect of education. Neuroepidemiology 1996; 15:20-25.

114. Jacobs DM, Marder K, Cote LJ, et al. Neuropsychological characteristics of preclinical dementia in Parkinson's disease. Neurology 1995; 45:1691-1696.

115. Levy G, Jacobs DM, Tang MX, et al. Memory and executive function impairment predict dementia in Parkinson's disease. Mov Disord 2002; 17:1221-1226.

116. Levy G, Tang MX, Cote LJ, et al. Do risk factors for Alzheimer's disease predict dementia in Parkinson's disease? An exploratory study. Mov Disord 2002; 17:250-257.

117. Fernandez HH, Lapane KL. Estrogen use among nursing home residents with a diagnosis of Parkinson's disease. Mov Disord 2000; 15:1119-1124.

118. Marder K, Tang MX, Alfaro B, et al. Postmenopausal estrogen use and Parkinson's disease with and without dementia. Neurology 1998; 50:1141-1143.

119. Marder K, Tang MX, Alfaro B, et al. Risk of Alzheimer's disease in relatives of Parkinson's disease patients with and without dementia. Neurology 1999; 52:719-724.

120. Hofman A, Schulte W, Tanja TA, et al. History of dementia and Parkinson's disease in 1st-degree relatives of patients with Alzheimer's disease. Neurology 1989; 39:1589-1592.

121. Parsian A, Racette B, Goldsmith LJ, Perlmutter JS. Parkinson's 
disease and apolipoprotein E: possible association with dementia but not age at onset. Genomics 2002; 79:458-461.

122. Koller WC, Glatt SL, Hubble JP, et al. Apolipoprotein E genotypes in Parkinson's disease with and without dementia. Ann Neurol 1995; 37:242-245.

123. Inzelberg R, Chapman J, Treves TA, et al. Apolipoprotein $\varepsilon 4$ in Parkinson disease and dementia: new data and meta-analysis of published studies. Alzheimer Dis Assoc Disord 1998; 12:45-48.

124. Harhangi BS, de Rijk MC, van Duijn CM, et al. APOE and the risk of PD with or without dementia in a population-based study. Neurology 2000; 54:1272-1276.

125. Wakabayashi K, Kakita A, Hayashi S, et al. Apolipoprotein E epsilon 4 allele and progression of cortical Lewy body pathology in Parkinson's disease. Acta Neuropathol (Berl) 1998; 95:450454.

126. Mattila PM, Koskela T, Roytta M, et al. Apolipoprotein E epsilon4 allele frequency is increased in Parkinson's disease only with coexisting Alzheimer pathology. Acta Neuropathol (Berl) 1998; 96:417-420.

127. Egensperger R, Bancher C, Kosel S, et al. The apolipoprotein E epsilon 4 allele in Parkinson's disease with Alzheimer lesions. Biochem Biophys Res Commun 1996; 224:484-486.

128. Li YJ, Scott WK, Hedges DJ, et al. Age at onset in two common neurodegenerative diseases is genetically controlled. Am J Hum Genet 2002; 70:985-993.

129. Zareparsi S, Camicioli R, Sexton G, et al. Age at onset of Parkinson disease and apolipoprotein E genotypes. Am J Med Genet 2002; 107:156-161.

130. Mattila KM, Rinne JO, Roytta M, et al. Dipeptidyl carboxypeptidase 1 (DCP1) and butyrylcholinesterase (BCHE) gene interactions with the apolipoprotein E epsilon4 allele as risk factors in Alzheimer's disease and in Parkinson's disease with coexisting Alzheimer pathology. J Med Genet 2000; 37:766-770.

131. Mattila KM, Rinne JO, Roytta M, Laippala P, Lehtimaki T. Lack of association between an estrogen receptor 1 gene polymorphism and Parkinson's disease with dementia. Acta Neurol Scand 2002; 106:128-130.

132. Isoe-Wada K, Maeda M, Yong J, et al. Positive association between an estrogen receptor gene polymorphism and Parkinson's disease with dementia. Eur J Neurol 1999; 6:431-435.

133. Egensperger R, Kosel S, Schnopp NM, Mehraein P, Graeber MB. Association of the mitochondrial tRNA(A4336G) mutation with Alzheimer's and Parkinson's diseases. Neuropathol Appl Neurobiol 1997; 23:315-321.

134. Tsuang DW, Dalan AM, Eugenio CJ, et al. Familial dementia with Lewy bodies: a clinical and neuropathological study of 2 families. Arch Neurol 2002; 59:1622-1630.

135. Galvin JE, Lee SL, Perry A, et al. Familial dementia with Lewy bodies: clinicopathologic analysis of two kindreds. Neurology 2002; 59:1079-1082.

136. Brett FM, Henson C, Staunton H. Familial diffuse Lewy body disease, eye movement abnormalities, and distribution of pathology. Arch Neurol 2002; 59:464-467.

137. St Clair D, Norrman J, Perry R, et al. Apolipoprotein E epsilon 4 allele frequency in patients with Lewy body dementia, Alzheimer's disease and age-matched controls. Neurosci Lett 1994; 176:45-46.

138. Benjamin R, Leake A, Ince PG, et al. Effects of apolipoprotein E genotype on cortical neuropathology in senile dementia of the Lewy body and Alzheimer's disease. Neurodegeneration 1995; 4:443-448.

139. Martinoli MG, Trojanowski JQ, Schmidt ML, et al. Association of apolipoprotein epsilon 4 allele and neuropathologic findings in patients with dementia. Acta Neuropathol (Berl) 1995; 90:239243.

140. Hardy J. Lewy bodies in Alzheimer's disease in which the primary lesion is a mutation in the amyloid precursor protein. Neurosci Lett 1994; 180:290-291.

141. Singleton AB, Gibson AM, McKeith IG, et al. Alpha2macroglobulin polymorphisms in Alzheimer's disease and dementia with Lewy bodies. Neuroreport 1999; 10:1507-1510.

142. Singleton AB, Lamb H, Leake A, et al. No association between a polymorphism in the presenilin 1 gene and dementia with Lewy bodies. Neuroreport 1997; 8:3637-3639.

143. Lamb H, Christie J, Singleton AB, et al. Apolipoprotein E and alpha-1 antichymotrypsin polymorphism genotyping in Alzheimer's disease and in dementia with Lewy bodies. Distinctions between diseases. Neurology 1998; 50:388-391.

144. Tanaka S, Chen X, Xia Y, et al. Association of CYP2D microsatellite polymorphism with Lewy body variant of Alzheimer's disease. Neurology 1998; 50:1556-1562.

145. Atkinson A, Singleton AB, Steward A, et al. CYP2D6 is associated with Parkinson's disease but not with dementia with Lewy bodies or Alzheimer's disease. Pharmacogenetics 1999; 9:31-35.

146. Payami H, Lee N, Zareparsi S, et al. Parkinson's disease, CYP2D6 polymorphism, and age. Neurology 2001; 56:1363-1370.

147. Chinnery PF, Taylor GA, Howell N, et al. Mitochondrial DNA haplogroups and susceptibility to AD and dementia with Lewy bodies. Neurology 2000; 55:302-304.

148. Takehashi M, Tanaka S, Masliah E, Ueda K. Association of monoamine oxidase A gene polymorphism with Alzheimer's disease and Lewy body variant. Neurosci Lett 2002; 327:79-82.

149. Farrer M, Skipper L, Berg M, et al. The tau H1 haplotype is associated with Parkinson's disease in the Norwegian population. Neurosci Lett 2002; 322:83-86.

150. Martin ER, Scott WK, Nance MA, et al. Association of singlenucleotide polymorphisms of the tau gene with late-onset Parkinson disease. JAMA2001; 286:2245-2250.

151. de Silva R, Hardy J, Crook J, et al. The tau locus is not significantly associated with pathologically confirmed sporadic Parkinson's disease. Neurosci Lett 2002; 330:201-203.

152. Spillantini MG, Goedert M. Tau and Parkinson disease. JAMA 2001; 286:2324-2326.

153. Scott WK, Nance MA, Watts RL, et al. Complete genomic screen in Parkinson disease: evidence for multiple genes. JAMA2001; 286:2239-2244.

154. Gwinn-Hardy K, Mehta ND, Farrer $M$, et al. Distinctive neuropathology revealed by alpha-synuclein antibodies in hereditary parkinsonism and dementia linked to chromosome $4 \mathrm{p}$. Acta Neuropathol (Berl) 2000; 99:663-672.

155. Gwinn-Hardy K. Genetics of parkinsonism. Mov Disord 2002; 17:645-656.

156. Dujardin K, Duhamel A, Becquet E, et al. Neuropsychological abnormalities in first degree relatives of patients with familial Parkinson's disease. J Neurol Neurosurg Psychiatry 1999; 67:323-328.

157. Montgomery EB Jr, Baker KB, Lyons K, Koller WC. Abnormal performance on the PD test battery by asymptomatic first-degree relatives. Neurology 1999; 52:757-762.

158. Richard IH, Papka M, Rubio A, Kurlan R. Parkinson's disease and dementia with Lewy bodies: one disease or two? Mov Disord 2002; 17:1161-1165.

159. Verghese J, Crystal HA, Dickson DW, Lipton RB. Validity of clinical criteria for the diagnosis of dementia with Lewy bodies. Neurology 1999; 53:1974-1982.

160. Hohl U, Tiraboschi P, Hansen LA, Thal LJ, Corey-Bloom J. Diagnostic accuracy of dementia with Lewy bodies. Arch Neurol 2000; 57:347-351.

161. Lopez OL, Becker JT, Kaufer DI, et al. Research evaluation and prospective diagnosis of dementia with Lewy bodies. Arch Neurol 2002; 59:43-46.

162. Aarsland D, Cummings JL, Larsen JP. Neuropsychiatric differences between Parkinson's disease with dementia and Alzheimer's disease. Int J Geriatr Psychiatry 2001; 16:184-191.

163. Aarsland D, Ballard C, Larsen JP, McKeith I. A comparative study of psychiatric symptoms in dementia with Lewy bodies and Parkinson's disease with and without dementia. Int J Geriatr Psychiatry 2001; 16:528-536.

164. Apaydin H, Ahlskog JE, Parisi JE, Boeve BF, Dickson DW. Parkinson disease neuropathology: later-developing dementia and loss of the levodopa response. Arch Neurol 2002; 59:102112.

165. Hurtig HI, Trojanowski JQ, Galvin J, et al. Alpha-synuclein cortical Lewy bodies correlate with dementia in Parkinson's disease. 
Neurology 2000; 54:1916-1921.

166. Goetz CG, Vogel C, Tanner CM, Stebbins GT. Early dopaminergic drug-induced hallucinations in parkinsonian patients. Neurology 1998; 51:811-814.

167. McKeith IG. Dementia with Lewy bodies. Br J Psychiatry 2002; 180:144-147.

168. Perry E, Court J, Goodchild R, et al. Clinical neurochemistry: developments in dementia research based on brain bank material. J Neural Transm 1998; 105:915-933.

169. Harding AJ, Stimson E, Henderson JM, Halliday GM. Clinical correlates of selective pathology in the amygdala of patients with Parkinson's disease. Brain 2002; 125:2431-2445.

170. Boeve BF, Silber MH, Ferman TJ, Lucas JA, Parisi JE. Association of REM sleep behavior disorder and neurodegenerative disease may reflect an underlying synucleinopathy. Mov Disord 2001; $16: 622-630$.

171. Arnulf I, Bonnet AM, Damier P, et al. Hallucinations, REM sleep, and Parkinson's disease: a medical hypothesis. Neurology 2000; 55:281-288.

172. Aarsland D, Ballard C, McKeith I, Perry RH, Larsen JP. Comparison of extrapyramidal signs in dementia with Lewy bodies and Parkinson's disease. J Neuropsychiatry Clin Neurosci 2001; 13:374-379.

173. Braak H, Tredici KD, Rub U, et al. Staging of brain pathology related to sporadic Parkinson's disease. Neurobiol Aging 2003; 24:197-211.

174. Jellinger KA, Seppi K, Wenning GK, Poewe W. Impact of coexistent Alzheimer pathology on the natural history of Parkinson's disease. J Neural Transm 2002; 109:329-339.

175. Mattila PM, Rinne JO, Helenius H, Dickson DW, Roytta M. Alphasynuclein-immunoreactive cortical Lewy bodies are associated with cognitive impairment in Parkinson's disease. Acta Neuropathol (Berl) 2000; 100:285-290.

176. Mattila PM, Roytta M, Torikka H, Dickson DW, Rinne JO. Cortical Lewy bodies and Alzheimer-type changes in patients with Parkinson's disease. Acta Neuropathol (Berl) 1998; 95:576-582.

177. de Vos RA, Jansen EN, Stam FC, Ravid R, Swaab DF. 'Lewy body disease': clinico-pathological correlations in 18 consecutive cases of Parkinson's disease with and without dementia. Clin Neurol Neurosurg 1995; 97:13-22.

178. Churchyard A, Lees AJ. The relationship between dementia and direct involvement of the hippocampus and amygdala in Parkinson's disease. Neurology 1997; 49:1570-1576.

179. Gomez-Tortosa E, Newell K, Irizarry MC, et al. Clinical and quantitative pathologic correlates of dementia with Lewy bodies. Neurology 1999; 53:1284-1291.

180. Masliah E, Rockenstein E, Veinbergs I, et al. Beta-amyloid peptides enhance alpha-synuclein accumulation and neuronal deficits in a transgenic mouse model linking Alzheimer's disease and Parkinson's disease. Proc Natl Acad Sci U S A 2001; 98:1224512250.

181. Hornykiewicz O. Dopamine miracle: from brain homogenate to dopamine replacement. Mov Disord 2002; 17:501-508.

182. Hornykiewicz O, Kish SJ. Neurochemical basis of dementia in Parkinson's disease. Can J Neurol Sci 1984; 11:185-190.

183. Chan-Palay V, Asan E. Alterations in catecholamine neurons of the locus coeruleus in senile dementia of the Alzheimer type and in Parkinson's disease with and without dementia and depression. J Comp Neurol 1989; 287:373-392.

184. D'Amato RJ, Zweig RM, Whitehouse PJ, et al. Aminergic systems in Alzheimer's disease and Parkinson's disease. Ann Neurol 1987; 22:229-236.

185. Mattila PM, Roytta M, Lonnberg P, et al. Choline acetytransferase activity and striatal dopamine receptors in Parkinson's disease in relation to cognitive impairment. Acta Neuropathol (Berl) 2001; 102:160-166.

186. Tiraboschi P, Hansen LA, Alford M, et al. Early and widespread cholinergic losses differentiate dementia with Lewy bodies from Alzheimer disease. Arch Gen Psychiatry 2002; 59:946-951.

187. Court JA, Piggott MA, Lloyd S, et al. Nicotine binding in human striatum: elevation in schizophrenia and reductions in dementia with Lewy bodies, Parkinson's disease and Alzheimer's disease and in relation to neuroleptic medication. Neuroscience 2000; 98:79-87.

188. Perry EK, Marshall E, Thompson P, et al. Monoaminergic activities in Lewy body dementia: relation to hallucinosis and extrapyramidal features. J Neural Transm Park Dis Dement Sect 1993; 6:167-177.

189. Joyce JN, Ryoo H, Gurevich EV, Adler C, Beach T. Ventral striatal $\mathrm{D}(3)$ receptors and Parkinson's disease. Parkinsonism Relat Disord 2001; 7:225-230.

190. Piggott MA, Marshall EF, Thomas N, et al. Striatal dopaminergic markers in dementia with Lewy bodies, Alzheimer's and Parkinson's diseases: rostrocaudal distribution. Brain 1999; 122 (Pt 8):1449-1468.

191. Joyce JN, Ryoo HL, Beach TB, et al. Loss of response to levodopa in Parkinson's disease and co-occurrence with dementia: role of $\mathrm{D}(3)$ and not $\mathrm{D}(2)$ receptors. Brain Res 2002; 955:138-152.

192. Ito K, Nagano-Saito A, Kato T, et al. Striatal and extrastriatal dysfunction in Parkinson's disease with dementia: a 6[18F]fluoro-L-dopa PETstudy. Brain 2002; 125:1358-1365.

193. Walker Z, Costa DC, Walker RW, et al. Differentiation of dementia with Lewy bodies from Alzheimer's disease using a dopaminergic presynaptic ligand. J Neurol Neurosurg Psychiatry 2002; 73:134-140.

194. Ransmayrl G, Seppi K, Donnemiller E, et al. Striatal dopamine transporter function in dementia with Lewy bodies and Parkinson's disease. Eur J Nucl Med 2001; 28:1523-1528.

195. Jagust WJ, Reed BR, Martin EM, Eberling JL, Nelson-Abbott RA. Cognitive function and regional cerebral blood flow in Parkinson's disease. Brain 1992; 115 (Pt 2):521-537.

196. Wu JC, Iacono R, Ayman M, et al. Correlation of intellectual impairment in Parkinson's disease with FDG PET scan. Neuroreport 2000; 11:2139-2144.

197. Wang SJ, Liu RS, Liu HC, et al. Technetium-99m hexamethylpropylene amine oxime single photon emission tomography of the brain in early Parkinson's disease: correlation with dementia and lateralization. Eur J Nucl Med 1993; 20:339344.

198. Peppard RF, Martin WR, Carr GD, et al. Cerebral glucose metabolism in Parkinson's disease with and without dementia. Arch Neurol 1992; 49:1262-1268.

199. Liu RS, Lin KN, Wang SJ, et al. Cognition and 99Tcm-HMPAO SPECT in Parkinson's disease. Nucl Med Commun 1992; 13:744-748.

200. Sawada H, Udaka F, Kameyama M, et al. SPECT findings in Parkinson's disease associated with dementia. J Neurol Neurosurg Psychiatry 1992; 55:960-963.

201. Spampinato U, Habert MO, Mas JL, et al. (99mTc)-HM-PAO SPECT and cognitive impairment in Parkinson's disease: a comparison with dementia of the Alzheimer type. J Neurol Neurosurg Psychiatry 1991; 54:787-792.

202. Turjanski N, Brooks DJ. PET and the investigation of dementia in the parkinsonian patient. J Neural Transm Suppl 1997; 51:37-48.

203. Tachibana H, Kawabata K, Tomino Y, Sugita M, Fukuchi M. Brain perfusion imaging in Parkinson's disease and Alzheimer's disease demonstrated by three-dimensional surface display with 123I-iodoamphetamine. Dementia 1993; 4:334-341.

204. Antonini A, De Notaris R, Benti R, De Gaspari D, Pezzoli G. Perfusion ECD/SPECT in the characterization of cognitive deficits in Parkinson's disease. Neurol Sci 2001; 22:45-46.

205. Goto I, Taniwaki T, Hosokawa S, et al. Positron emission tomographic (PET) studies in dementia. J Neurol Sci 1993; 114:1-6.

206. Vander Borght T, Minoshima S, Giordani B, et al. Cerebral metabolic differences in Parkinson's and Alzheimer's diseases matched for dementia severity. J Nucl Med 1997; 38:797-802.

207. Imamura T, Ishii K, Hirono N, et al. Occipital glucose metabolism in dementia with lewy bodies with and without parkinsonism: a study using positron emission tomography. Dement Geriatr Cogn Disord 2001; 12:194-197.

208. Kuhl DE, Minoshima S, Fessler JA, et al. In vivo mapping of cholinergic terminals in normal aging, Alzheimer's disease, and Parkinson's disease. Ann Neurol 1996; 40:399-410. 
209. Defebvre LJ, Leduc V, Duhamel A, et al. Technetium HMPAO SPECTstudy in dementia with Lewy bodies, Alzheimer's disease and idiopathic Parkinson's disease. J Nucl Med 1999; 40:956962.

210. Donnemiller E, Heilmann J, Wenning GK, et al. Brain perfusion scintigraphy with $99 \mathrm{mTc}-\mathrm{HMPAO}$ or $99 \mathrm{mTc}-\mathrm{ECD}$ and $123 \mathrm{I}-$ beta-CIT single-photon emission tomography in dementia of the Alzheimer-type and diffuse Lewy body disease. Eur J Nucl Med 1997; 24:320-325.

211. Lobotesis K, Fenwick JD, Phipps A, et al. Occipital hypoperfusion on SPECT in dementia with Lewy bodies but not AD. Neurology 2001; 56:643-649.

212. Ishii K, Yamaji S, Kitagaki H, et al. Regional cerebral blood flow difference between dementia with Lewy bodies and AD. Neurology 1999; 53:413-416.

213. Colloby SJ, Fenwick JD, Williams ED, et al. A comparison of $(99 \mathrm{~m}) \mathrm{Tc}-\mathrm{HMPAO}$ SPECT changes in dementia with Lewy bodies and Alzheimer's disease using statistical parametric mapping. Eur J Nucl Med Mol Imaging 2002; 29:615-622.

214. Varma AR, Talbot PR, Snowden JS, et al. A 99mTc-HMPAOsinglephoton emission computed tomography study of Lewy body disease. J Neurol 1997; 244:349-359.

215. Alegret M, Junque C, Pueyo R, et al. MRI atrophy parameters related to cognitive and motor impairment in Parkinson's disease. Neurologia 2001; 16:63-69.

216. Hu MT, White SJ, Chaudhuri KR, et al. Correlating rates of cerebral atrophy in Parkinson's disease with measures of cognitive decline. J Neural Transm 2001; 108:571-580.

217. Laakso MP, Partanen K, Riekkinen P, et al. Hippocampal volumes in Alzheimer's disease, Parkinson's disease with and without dementia, and in vascular dementia: an MRI study. Neurology 1996; 46:678-681.

218. Cordato NJ, Pantelis C, Halliday GM, et al. Frontal atrophy correlates with behavioural changes in progressive supranuclear palsy. Brain 2002; 125:789-800.

219. Camicioli R, Moore M, Kinney A, et al. Parkinson's disease is associated with hippocampal atrophy. Mov Disord 2003;18:784-790.

220. Hashimoto M, Kitagaki H, Imamura T, et al. Medial temporal and whole-brain atrophy in dementia with Lewy bodies: a volumetric MRI study. Neurology 1998; 51:357-362.

221. Harvey GT, Hughes J, McKeith IG, et al. Magnetic resonance imaging differences between dementia with Lewy bodies and Alzheimer's disease: a pilot study. Psychol Med 1999; 29:181-187.

222. Barber R, Ballard C, McKeith IG, Gholkar A, O'Brien JT. MRI volumetric study of dementia with Lewy bodies: a comparison with AD and vascular dementia. Neurology 2000; 54:1304-1309.

223. Barber R, McKeith IG, Ballard C, Gholkar A, O'Brien JT. A comparison of medial and lateral temporal lobe atrophy in dementia with Lewy bodies and Alzheimer's disease: magnetic resonance imaging volumetric study. Dement Geriatr Cogn Disord 2001; 12:198-205.

224. Hanyu H, Asano T, Sakurai H, et al. MR analysis of the substantia innominata in normal aging, Alzheimer disease, and other types of dementia. AJNR Am J Neuroradiol 2002; 23:27-32.

225. O'Brien JT, Paling S, Barber R, et al. Progressive brain atrophy on serial MRI in dementia with Lewy bodies, AD, and vascular dementia. Neurology 2001; 56:1386-1388.

226. Barber R, McKeith I, Ballard C, O’Brien J. Volumetric MRI study of the caudate nucleus in patients with dementia with Lewy bodies, Alzheimer's disease, and vascular dementia. J Neurol Neurosurg Psychiatry 2002; 72:406-407.

227. Middelkoop HA, van der Flier WM, Burton EJ, et al. Dementia with Lewy bodies and AD are not associated with occipital lobe atrophy on MRI. Neurology 2001; 57:2117-2120.

228. Barber R, Scheltens P, Gholkar A, et al. White matter lesions on magnetic resonance imaging in dementia with Lewy bodies, Alzheimer's disease, vascular dementia, and normal aging. J Neurol Neurosurg Psychiatry 1999; 67:66-72.

229. Hu MT, Taylor-Robinson SD, Chaudhuri KR, et al. Evidence for cortical dysfunction in clinically non-demented patients with Parkinson's disease: a proton MR spectroscopy study. J Neurol Neurosurg Psychiatry 1999; 67:20-26.
230. Molina JA, Garcia-Segura JM, Benito-Leon J, et al. Proton magnetic resonance spectroscopy in dementia with Lewy bodies. Eur Neurol 2002; 48:158-163.

231. Bhattacharya K, Saadia D, Eisenkraft B, et al. Brain magnetic resonance imaging in multiple-system atrophy and Parkinson disease: a diagnostic algorithm. Arch Neurol 2002; 59:835-842.

232. Saint-Cyr JA, Trepanier LL. Neuropsychologic assessment of patients for movement disorder surgery. Mov Disord 2000; 15:771-783.

233. Jahanshahi M, Ardouin CM, Brown RG, et al. The impact of deep brain stimulation on executive function in Parkinson's disease. Brain 2000; 123 (Pt 6):1142-1154.

234. Patterson C, Gauthier S, Bergman H, et al. The recognition, assessment and management of dementing disorders: conclusions from the Canadian Consensus Conference on Dementia. Can J Neurol Sci 2001; 28 (Suppl 1):S3-S16.

235. Chertkow H, Bergman H, Schipper HM, et al. Assessment of suspected dementia. Can J Neurol Sci 2001; 28 (Suppl 1):S28-41.

236. Hogan DB, Jennett P, Freter S, et al. Recommendations of the Canadian Consensus Conference on Dementia--dissemination, implementation, and evaluation of impact. Can J Neurol Sci 2001; 28 (Suppl 1):S115-S121.

237. Shulman LM, Singer C, Levin B, Weiner WJ. Diagnostic testing for dementia in patients with Parkinson's disease. J Am Geriatr Soc 1996; 44:214-215.

238. Hejl A, Hogh P, Waldemar G. Potentially reversible conditions in 1000 consecutive memory clinic patients. J Neurol Neurosurg Psychiatry 2002; 73:390-394

239. Bayles KA, Tomoeda CK, Wood JA, et al. Change in cognitive function in idiopathic Parkinson disease. Arch Neurol 1996; 53:1140-1146.

240. Jefferson AL, Cosentino SA, Ball SK, et al. Errors produced on the mini-mental state examination and neuropsychological test performance in Alzheimer's disease, ischemic vascular dementia, and Parkinson's disease. J Neuropsychiatry Clin Neurosci 2002; 14:311-320.

241. Rothlind JC, Brandt J. A brief assessment of frontal and subcortical functions in dementia. J Neuropsychiatry Clin Neurosci 1993; 5:73-77.

242. Huber SJ, Shuttleworth EC, Christy JA, Rice RR. A brief scale for the dementia of Parkinson's disease. J Neuropsychiatry Clin Neurosci 1990; 2:183-188.

243. Cubo E, Bernard B, Leurgans S, Raman R. Cognitive and motor function in patients with Parkinson's disease with and without depression. Clin Neuropharmacol 2000; 23:331-334.

244. Norman S, Troster AI, Fields JA, Brooks R. Effects of depression and Parkinson's disease on cognitive functioning. J Neuropsychiatry Clin Neurosci 2002; 14:31-36.

245. Beck AT, Steer RA, Brown GK. BDI-II, Beck Depression Inventory: Manual. San Antonio, Texas: Psychological Corp. Harcourt Brace, 1996.

246. Hamilton M. Development of a rating scale for primary depressive illness. Br J Soc Clin Psychol 1967; 6:278-296.

247. Yesavage JA. Geriatric Depression Scale. Psychopharmacol Bull 1988; 24:709-711.

248. Alexopoulos GS, Abrams RC, Young RC, Shamoian CA. Cornell Scale for Depression in Dementia. Biol Psychiatry 1988; 23:271284.

249. de Smet Y, Ruberg M, Serdaru M, et al. Confusion, dementia and anticholinergics in Parkinson's disease. J Neurol Neurosurg Psychiatry 1982; 45:1161-1164.

250. Cooper JA, Sagar HJ, Doherty SM, et al. Different effects of dopaminergic and anticholinergic therapies on cognitive and motor function in Parkinson's disease. A follow-up study of untreated patients. Brain 1992; 115 (Pt 6):1701-1725.

251. Dubois B, Pilon B, Lhermitte F, Agid Y. Cholinergic deficiency and frontal dysfunction in Parkinson's disease. Ann Neurol 1990; $28: 117-121$

252. Pondal M, Del Ser T, Bermejo F. Anticholinergic therapy and dementia in patients with Parkinson's disease. J Neurol 1996; 243:543-546.

253. Bedard MA, Pillon B, Dubois B, et al. Acute and long-term 
administration of anticholinergics in Parkinson's disease: specific effects on the subcortico-frontal syndrome. Brain Cogn 1999; 40:289-313.

254. Miyasaki JM, Grimes D, Lang AE. Acute delirium after withdrawal of amantadine in Parkinson's disease. Neurology 1999; 52:17201721.

255. Factor SA, Molho ES, Brown DL. Acute delirium after withdrawal of amantadine in Parkinson's disease. Neurology 1998; 50:1456-1458.

256. Reimer J, Kuhlmann A, Muller T. Neuroleptic malignant-like syndrome after rapid switch from bromocriptine to pergolide. Parkinsonism Relat Disord 2002; 9:115-116.

257. Ueda M, Hamamoto M, Nagayama H, et al. Biochemical alterations during medication withdrawal in Parkinson's disease with and without neuroleptic malignant-like syndrome. J Neurol Neurosurg Psychiatry 2001; 71:111-113.

258. Reutens DC, Harrison WB, Goldswain PR. Neuroleptic malignant syndrome complicating levodopa withdrawal. Med J Aust 1991; 155:53-54.

259. Weller M, Kornhuber J. Amantadine withdrawal and neuroleptic malignant syndrome. Neurology 1993; 43:2155.

260. Friedman JH, Fernandez HH. Atypical antipsychotics in Parkinsonsensitive populations. J Geriatr Psychiatry Neurol 2002; 15:156-170.

261. Tarsy D, Baldessarini RJ, Tarazi FI. Effects of newer antipsychotics on extrapyramidal function. CNS Drugs 2002; 16:23-45.

262. The Parkinson Study Group. Low-dose clozapine for the treatment of drug-induced psychosis in Parkinson's disease. The Parkinson Study Group. N Engl J Med 1999; 340:757-763.

263. Goetz CG, Blasucci LM, Leurgans S, Pappert EJ. Olanzapine and clozapine: comparative effects on motor function in hallucinating PD patients. Neurology 2000; 55:789-794.

264. Ondo WG, Levy JK, Vuong KD, Hunter C, Jankovic J. Olanzapine treatment for dopaminergic-induced hallucinations. Mov Disord 2002; 17:1031-1035.

265. Gimenez-Roldan S, Mateo D, Navarro E, Gines MM. Efficacy and safety of clozapine and olanzapine: an open-label study comparing two groups of Parkinson's disease patients with dopaminergic-induced psychosis. Parkinsonism Relat Disord 2001; 7:121-127.

266. Walker Z, Costa DC, Ince P, McKeith IG, Katona CL. In-vivo demonstration of dopaminergic degeneration in dementia with Lewy bodies. Lancet 1999; 354:646-647.

267. Reddy S, Factor SA, Molho ES, Feustel PJ. The effect of quetiapine on psychosis and motor function in parkinsonian patients with and without dementia. Mov Disord 2002; 17:676-681.
268. Fernandez HH, Trieschmann ME, Burke MA, Friedman JH. Quetiapine for psychosis in Parkinson's disease versus dementia with Lewy bodies. J Clin Psychiatry 2002; 63:513-515.

269. Seeman P. Atypical antipsychotics: mechanism of action. Can J Psychiatry 2002; 47:27-38.

270. Duvoisin RC. Cholinergic-anticholinergic antagonism in parkinsonism. Arch Neurol 1967; 17:124-136.

271. Richard IH, Justus AW, Greig NH, Marshall F, Kurlan R. Worsening of motor function and mood in a patient with Parkinson's disease after pharmacologic challenge with oral rivastigmine. Clin Neuropharmacol 2002; 25:296-299.

272. McKeith I, Del Ser T, Spano P, et al. Efficacy of rivastigmine in dementia with Lewy bodies: a randomised, double-blind, placebocontrolled international study. Lancet 2000; 356:2031-2036.

273. Reading PJ, Luce AK, McKeith IG. Rivastigmine in the treatment of parkinsonian psychosis and cognitive impairment: preliminary findings from an open trial. Mov Disord 2001; 16:1171-1174.

274. Bullock R, Cameron A. Rivastigmine for the treatment of dementia and visual hallucinations associated with Parkinson's disease: a case series. Curr Med Res Opin 2002; 18:258-264.

275. Fabbrini G, Barbanti P, Aurilia C, et al. Donepezil in the treatment of hallucinations and delusions in Parkinson's disease. Neurol Sci 2002; 23:41-43.

276. Bergman J, Lerner V. Successful use of donepezil for the treatment of psychotic symptoms in patients with Parkinson's disease. Clin Neuropharmacol 2002; 25:107-110.

277. Aarsland D, Laake K, Larsen JP, Janvin C. Donepezil for cognitive impairment in Parkinson's disease: a randomised controlled study. J Neurol Neurosurg Psychiatry 2002; 72:708-712.

278. Werber EA, Rabey JM. The beneficial effect of cholinesterase inhibitors on patients suffering from Parkinson's disease and dementia. J Neural Transm 2001; 108:1319-1325.

279. Hutchinson M, Fazzini E. Cholinesterase inhibition in Parkinson's disease. J Neurol Neurosurg Psychiatry 1996; 61:324-325.

280. Kelton MC, Kahn HJ, Conrath CL, Newhouse PA. The effects of nicotine on Parkinson's disease. Brain Cogn 2000; 43:274-282.

281. Jann MW, Shirley KL, Small GW. Clinical pharmacokinetics and pharmacodynamics of cholinesterase inhibitors. Clin Pharmacokinet 2002; 41:719-739.

282. Santos MD, Alkondon M, Pereira EF, et al. The nicotinic allosteric potentiating ligand galantamine facilitates synaptic transmission in the mammalian central nervous system. Mol Pharmacol 2002; 61:1222-1234. 